\title{
SULPHUR AS A FACTOR IN SOIL FERTILITY
}

\author{
A DISSERTATION \\ SUBMITTED TO THE FACULTY \\ OF THE OGDEN GRADUATE SCHOOL OF SCIENCE \\ IN CANDIDACY FOR THE DEGREE OF \\ DOCTOR OF PHILOSOPHY
}

DEPARTMENT OF BOTANY

BY

JOHN WOODARD

Private Edition, Distributed By

THE UNIVERSITY OF CHICAGO LIBRARIES

CHICAGO, ILLINOIS

Reprinted from

The Botanical Gazette, Vol. LXXIII, No. 2, February, I922 



\title{
SULPHUR AS A FACTOR IN SOIL FERTILITY
}

\author{
A DISSERTATION \\ SUBMITTED TO THE FACULTY \\ OF THE OGDEN GRADUATE SCHOOL OF SCIENCE \\ IN CANDIDACY FOR TIIE DEGREE OF \\ DOCTOR OF PHILOSOPHY \\ DEPARTAENT OF BOTANY \\ BY \\ JOHN WOODARD
}

Private Edition, Distributed By

THE UNIVERSITY OF CHICAGO LIBRARIES

CHICAGO, ILLINOIS

Reprinted from

The Botanical Gazette, Vol. LXXIII, No. 2, February, I922 
Gift

Univergidy

ใ28 241028 


\section{THE}

\section{BOTANICAL GAZETTE}

February' 1022

SULPHUR AS A FACTOR IN SOIL FERTUITY

CONTRIBTTIONS FRON THE HULL BOTANTCAL LABORATORY 289

JOII $\times$ II OOD I R D

\section{Introduction}

Although sulphur was recognized as an essential element in plant nutrition as early as the middle of the nineteenth century, the use of sulphur and sulphur compounds as fertilizers has never become general. Analyses for sulphur in soils have generally been low, yet when compared with the sulphur in the ash of plants, the amount present in the soil seemed sufficient for all the needs of the crop. The use of gypsum as a fertilizer, however, was quite extensive for a time, following the discovery of its beneficial effect on plants. BRowne (I3) credits this discovery to a clergyman in Germany in 1768 . From there it spread to France and Great Britain, and was brought to the United States by Benjanin FRANkLIN, who used it on his farm near Philadelphia. For a time gypsum was extensively used as a fertilizer both in Europe and the United States and gave remarkable results. GRIFFITHS (25) reports experiments by SCHubert in Germany, and CROCKER (I5) refers to the experiments of Judge Peters, John Binns, and Edrund RUFFIv in the United States. All these men obtained remarkable results with gypsum on legumes.

The use of gypsum alone, however, soon failed to increase crop yields, and investigators seeking for an explanation came to the conclusion that the gypsum acts chemically on the phosphorus or potassium compounds in the soil and liberates either phosphorus or 
potassium or both. This view is presented by (iRffirtus (25),

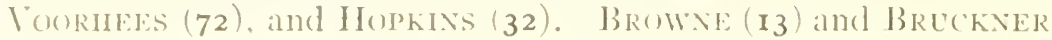
(I4) ansider the beneficial effect of erposum (lue, in part at least, to the nutrient effect of the sulphur; while Vixblumas (70) and III.c.LRD (3I) mention its beneficial effects, particularly on the legumes, without giving any explanation.

In most fertilizer experiments sulphur has been added, together with plosphorus, in acid phosphate or basic slag. or with the potassium in potassium sulphate or kainit. When beneficial results have been obtained. the investigators have invariably ignored the possible effects of the sulphur. This may lead to erroneous conclusions, as was pointed out by Lienig (37) in $8_{55}$. He said that the sulphur or the calcium in the acid phosphate, or both, might have harl a beneficial effect on the turnips in the Rothamsted experiments, as well as the phosphorus.

Hopkiss. Mosier, Pettit, and Readnumer (33) found that kininit increased the yields of corn. wheat, and oats on the waste hill land of Johnson County, Illinois, when used with bonemeal, ground limestone, and crop residues, over similarly treated plots without kainit. On the plots receiving no kainit, as well as on those receiving the kainit, cowpeas were grown once every three years and turned under as part of the crop residues. STEWART (66) compared potassium chloride and potassium sulphate as fertilizers for apple orchards in Pennsylvania. He found no appreciable difference in the effect of these salts. Surti (65) found a greater yield of oat straw for potassium sulphate than potassium chloride in pots containing Hagerstown silt loam.

Brooks (8) compared the effects of potassium sulphate and potassium chloride on alfalia in field experiments at the Massachusetts Agricultural Experiment Station. Both plots received 600 pounds of bonemeal per annum. and both recaived 2 tons per acre of hylrated lime before planting the alfalfa. Both Grimm alfalfi and common alfalfa were used. Potassium sulphate gave increased yields of 0.50 tons of Grimm alfalia and 0.75 tons of common alfalfa over potassium chloride. In crery case the alfalfa on the plots receiving potassium sulphate was a darker green than on the plots receiving potasium chloricle. The same difference in color 
was reported for the same treatment on other crops. BRooks (9) also made a comparison of different phosphate fertilizers. He found that acid phosphate and dissolved boneblack, which contain sulphur, gave greater increases in crop yields than raw bonemeal and rock phosphate, which contain little or no sulphur. A more rapid early growth of both tops and roots and earlier maturity were observed on the plots receiving the dissolved boneblack and acid phosphate than on the plots receiving raw bonemeal and rock phosphate.

The use of flowers of sulphur as a fertilizer was observed to have an influence aside from its effect in destroying the fungi which cause plant diseases. MAREs (50) noticed a much greater vigor in vines that had been sulphured than in those which had not. He found that the sulphur was oxidized to sulphuric acid in the soil, and he thought that the sulphuric acid acted on the insoluble compounds containing potassium and made the potassium soluble. DEMoLon (r6) found that heating the soil prevented the oxidation, and so he concluded that oxidation was caused by microorganisms. Pfeiffer and BLANCK (56) obtained no increased yields of oats for the use of flowers of sulphur in field experiments. Feilitzen (2I) in Europe, and Sherbakoff (64) in the United States both obtained increased yields of potatoes from the use of flowers of sulphur.

Boullanger and Dugardin (3) found flowers of sulphur increased ammonification but decreased nitrification. The harmful effect on the nitrifying bacteria was probably due to the acidity, as LINT (38) found that the oxidation of sulphur in the soil increased the acidity very much. FRED and HART (23) report an increase in ammonification from the use of gypsum in peptone solutions, and WARINGTON (73) obtained an increase in nitrification when gypsum was applied to solutions of urea. Greaves, CARTER, and Goldthorpe (24) studied the influence of calcium sulphate on production of nitrates and found it caused a great increase in all concentrations used. The increase was very high for the higher concentrations of calcium sulphate.

Brioux and GUerbet (7) found that flowers of sulphur increased availability of calcium and potassium in both calcareous 
and noncalareous soils, but had no efïect on phosphorus. LipMIV and Mclers. (42) fomme that composting rock phosphate with sulphur increased the solubility of phosphorus. McLlix (48) found an increase of solubility of phosphorus in the sulphurrock phosphate compost when compost was inoculated. The presence of soluble phosphates and sulphates diul not inhibit the action. LapulN. MCLEN, and LINT (43) found a great increase in acidity in the sulphur-floats mixture. Lip.us and JofFe (4I) foumel no increased arailability in phosphorus when acility wat increased by the aldition of sulphuric acid. ELLETL and II IRRIs (20) found greater avilability of plosphorus in a manure-soilfloats-sulphur compost than in a soil-thoats-sulphur compost. Ams and Remmoxo (2) found no increaserl avalability of phosphorus in a compost to which calcium carbonate had been arded. Aciel conditions are necessary for the solution of the phosphorus. Browe and Givix ( Io) found an increased solubility of phosphorus in soil treated with sulphur as well as in composts. BRow and W.ARALR (12) found no increased solubility of phosphorus in a manure-floats compost, but a great increase when flowers of sulphur were adeled to the compost.

The use of ergesum as a preservative of the nitregen in manume

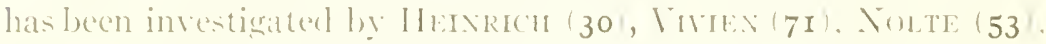

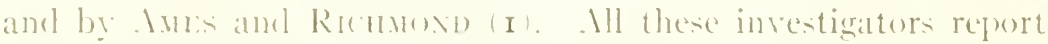
a saving of nitrogen from the use of ergetum on the manure.

Inventigations on the ellete of flowers of sulphur on the arailability of potasium in ereensames were conducted by Mc( Mir. and sinen 45. 'They found an jucrease in the avalability of potansium in composts of subphur, seremsinds, and manure, lut no increase in alvalalility of potassium in composts of sulphur. erreansilnels, amel soil.

Reprorts of investigaters who sturlied the influence of grpsum

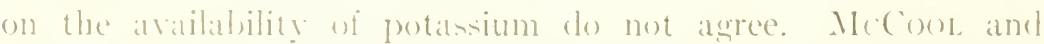
MILLAR 46 fumel alcium sulphate applied to soil bowered the freeging point of the soil. Voreport wats given at to the character

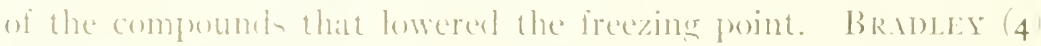
founct an increase in solubility of potasitum but not of phosphorus

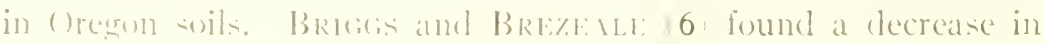


solubility of potassium in California soils when gypsum was added, and the solubility of potassium decreased as the amount of gypsum used was increased. BREzEALE and BRIGGS (5) grew wheat in water cultures, using extracts from orthoclase minerals with and without gypsum. The gypsum dirl not increase the availability of the potassium to the wheat. Morse and Curry (52) treated feldspars with gypsum for ten weeks in water, filtered off the solution and analyzed for potassium. Only slightly more potassium was found than when no gypsum was used. McMild.iR (49) treated five different soils with gypsum for three months and analyzed for soluble potassium. Ciypsum was used at the rate of ten tons per acre and resulted in an increase in soluble potassium in every case. Tressler (69) found an increase in soluble potassium in some soils, but no increase in others when treated with gypsum. LIPMAN and GERICKE (39) obtained an increase of available potassium in greenhouse soil, a slight increase in adobe soil, and no increase in sand. FRAPS (22) grew plants in pots of soil treated with gypsum and analyzed the plants for potassium. He found no increase in potassium in plants grown on the gypsum-treated soil above that on the soil without gypsum. He reports no analyses of the soils used, however, so it is not known whether these soils were deficient in potassium or not. If the soil has sufficient potassium in an available form to supply all the plants' needs, there would not likely be any increased absorption even if the soil treatment dissolved some of the insoluble potassium compounds in the soil. On the other hand, in a soil deficient in potassium and sulphur, the a]plication of gypsum or any other fertilizer containing sulphur would stimulate the growth of roots, and the increased size of the root system would make it possible for the plant to absorb more potassium. This increased absorption would take place regardless of any possible effects on the solubility of the potassium compounds in the soil.

The experiments of MCMILLAR (49), Tressler (69), and LIPMAN (39) indicate a greater solubility of potassium in some soils when treated with gypsum, but other soils show no effect, while BrIgGs and BREzEALE (6) report a decrease in solubility when gypsum was used. It seems, therefore, that the beneficial 
chects of gifstm can hardly be atscribel to its effect on the solubility of the potatsium in the soil. It seems more likely that the soils that responel to the use of grysum are deficient in some element that is supplied by the sypesum.

Recent sturlies of methods for the analysis of organic material for sulphur have shown that all the sulphur is not recovered in the ash when organic material is loumed. HoRT and PETERson $(27,28)$ found one hundred times as much s() ${ }_{3}$ in the rice grain ats in the ats of that gratin, and forty times as much in the corn grain. Similar results were obtained with other grains, but the ratios were less in some catses. (Onions, potaloes, crucifers, and legumes use large quantities of sulphur. Alfalfa removes twice ats much sulphur as phosphorus from the soil. Pererson (55) studied the sulphur compounds in plants and found proteins, volatile compounds, mustard oils. and sulphates. In ashing the plant material the suphates remain, but at best part of the sulphur in other compounds is lost. Most soils are low in sulphur, which is present in the soil in the form of sulphates and organic matter. Sulphates are all soluble, and, like nitrates, they are not aclsorbed to any great extent, and therefore are quickly leached out of the soil in the humid regions. The organic sulphur is insoluble but is readily oxidized to sulphates, so that it is gradually being lost unless taken up by the plant. LYoN and BIZZELL (44) in their lysimeter studies at Cornell found that the loss of sulphur in the drainage from uncropped lysimeters was as great as the loss in drainage and in the crops from cropped soil. The oxidation of organic sulphur to sulphates seemed to continue at the same rate in cropped and uncropped soil, and that not taken up by plants was lost in the drainage.

Cultivation stimulates oxidation and consequently the loss of sulphour. Swhsox and Mrleke (68) report a loss of 38.53 per (ent of sulphur from the surface and $4 \mathrm{I}_{5} \mathrm{5}^{\circ}$ per cent from the subsoil of hansas soils due to cropping. 'The surface soil of virgin land harl 0.044 per cent sulphur, while adjoining cropped land had 0.027 per cent. The sulphur content of the subsoil was 0.062 per cent in the virgin land and 0.036 per cent in the cropped land. () the other hand, phosphorus was practically the same in the 
cropped as in the virgin land in both surface and subsoil. The cultivated soils had been cropped for thirty to forty years.

Lyon and Brzzell (44) found an increased loss of sulphur in the drainage when burnt lime was used, while MacIntire, Willis, and HoldiNG (47) found the loss greater for calcium carbonate than for calcium oxide. It seems the carbonate favors bacterial action much more than the oxide.

Robinson $(59,60)$ analyzed a large number of soil samples from different parts of the United States for sulphur and phosphorus. Most of them were low, some extremely low, in both phosphorus and sulphur. Many of the samples were much lower in sulphur than phosphorus. BRown and KELLOGG (II) analyzed samples of Iowa soils and found the sulphur content varied from 7 i 9 to $93 \mathrm{~S}$ pounds per acre in the surface soil, while the phosphorus content varied from I 289 to 1538 pounds per acre. SHEdD (62) analyzed samples of Kentucky soils and found the sulphur content in the surface soil varied from 2 I 3 to roSo pounds per acre in virgin soil, and from iso to 560 pounds per acre in cultivated soils. The phosphorus content in the surface soil ranged from 320 to 5860 pounds in virgin soil, and from 320 to 7240 pounds in cultivated soil.

Some sulphur is brought down froni the air in rain water. The amount is probably greater during periods of heavy rainfall than when the precipitation is slight. Near cities, where a large amount of coal is bumed, the amount is probably much greater than in country districts far from cities and railroads. The data, however, are too meager to form any definite conclusions. HALL (26) reports sulphur analyses of rain water at Rothamsted from 1 SS I to 1887 which give an annual average of seven pounds of sulphur in the rainwater per acre per year. Analyses by HART and PETERSON (27) at the University of Wisconsin for part of a year led them to the conclusion that the amount in one year would be approximately the sime as found at Rothamsted. STEWART (67) analyzed rain water at the University of Illinois and obtained as a seven-year average 45. I pounds of sulphur per amnum. All of these analyses are of rain water collected near cities. The water in the rain gauges is likely to be contaminated by dust and soot and by the droppings of birds which roost on the rain gauges. 
L, IWIS and (ill:RE 136 found, in their fertilizer experiments with red closer, that "the proluce was comsiderably increased hy the application of gypsum, ant still more so hy that of the sul-

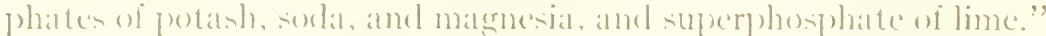
In four years the inereased yedel from the use of eypeum was 3.5 tons of dry hay or an atreratge of o.o tom per acre per year.

Hot 35 \% at the Pennsylania Agricultural Evperiment stat tion, used gypsum in a rotation of corm, oats. wheat. and hay (timothy and clover). (iypsum was applied at the rate of 320 poumbls per acre per rotation in two applications. soo pounds to the corn and 100 poumds to the wheat. No other fertilizers were used, and no increases in vields were obtained from the use of grypsum. These experiments woulel be more valualse it the ergesum hatel been afplied to the elover and other fertilizers hat been used to remove the posibility of another bimiting factor.

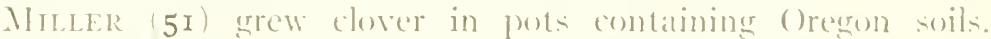
Applications of sulphur were mate in the form of flowers of sulphur, sodium sulphate, and gypsum. (ivpsum and sorljum sulphate gave increased yielels, hut the flowers of sulphour lad litule effect.

SOURIANER (6I) studiexl the effeet of different salts on oxidation in soil extracts in which wheat seedlings were grown. He reports increatised oxjelation from the use of calcium sulphate, potassium sulphate, and sodium sulphate.

I) Yuoxu, flecilles, and Jope (I8) compared the effect of ammonimm sulphate and ammonim chloride on cabbages grown on mon-calcarcous soil. Greater vields were olstalined with the ammonium sulphate than with the ammonium chloride. In their experiments with clower they obtained at 20 per cent increase in hat from the use of eypoum. In pastures they ohserved that legumen preflominated where sulphates were applied, and grasses where no sulphates were used. (ivpsum increased the vields of red clover, malize, and vetch in sant cultures. and of retel in soil cultures. . 1ll the pots received applications of calcium and magrnesjum cartonates.

I.IPMAx and (iERICke (40) comparerl the eifects of different nitrogenous fertilizers on barley grown on ()akley's vitro sand, and found the greatest increase with ammonium sulphate. When 
sulphur containing substances were added to the non-sulphur containing nitrogenous fertilizers, they produced yields equal to those from ammonium sulphate.

SHed (63) grew soy beans, oats, alfalfa, and wheat in pots containing Kentucky soils. Eight different soils were used, and flowers of sulphur added at the rate of 100 and 200 pounds per acre. Both controls and sulphur treated pots received tricalcium phosphate, potassium nitrate, and calcium carbonate. There were some increases but also some rlecreases.

EATON (I9) grew sweet corn in pots containing sand. He compared the effect of gypsum, flowers of sulphur, and sodium sulphate. The controls as well as the different sulphur treatments were watered with a nutrient solution which contained no sulphur. Gypsum increased the yield, while flowers of sulphur and sodium sulphate gave increases for the smaller applications and decreases for the larger applications.

DULEY (I7) reported a clarker green in sweet clover and corn when fertilized with gypsum or sulphur. Nore nodules were also produced on the roots.

PITz (57) grew clover in agar-agar containing dipotassium phosphate with and without calcium sulphate. Greater length of roots was obtained with the calcium sulphate. Clover was also grown in Miami silt loam with and without calcium sulphate. The calcium sulphate increased the root length.

HART and TOTTINGHAM (29) found a decided increase in development of beans, red clover, and peas when fertilized with either calcium sulphate or sodium sulphate. In beans and peas the increase was in the seed, in clover it was in the hay and roots. Sulphates increased the yiclds of both tops and roots in radishes. The yield of rape tops was increased by both calcium and sodium sulphates. Barley was not affected by the sulphates, and oats to only a slight extent.

OLson (54) conducted field experiments with alfalfa at the Washington Agricultural Experiment Station and obtaines increased yields from the use of acid phosphate and gypsum, but not from other forms of phosphorus. Two hundred pounds of gypsum per acre increased the yields of alfalfa from ioo to 500 per cent. 
RFur R and T.MRTAR (58) conducted field experiments on sevral (Oregon soils. Superphosphate. mowers of sulphur, rock phosphate, potassum chloride, potasiom sulphate, irom suphate. erypsum, monocalcium phosphate, solimm nitrate. ammonium suphate, magnesium sulphate, soclium sulphate, iron prites, fuick lime, and ground limestone were used as fertilizers. In almost wery case enormous increases in viekls from two to ten times at much as the checks) were obtained for all the fertilizers containing sulphur, and no increass or only a small increase for the fertilizers which contained no sulphur. Aciol phosphate was compared with gypum and rock phosphate and with rock phosphate and howers of sulphur. The yeld on the plot receiving rock phosphate and gypsum was considerably greater. and that from the plot receiving rock phosplote and llowers of sulphur slightly greater, than the vield from the acid phosphate treated plot. The alfalia on all the plots receiving sulphur in any form was a clarker green than on the plots which received no suphur.

(hemical analyses of soil samples from these experimental fiekls were made. The sulphur content varied from 0.015 to 0.0 . is per cent in the surface soil, and from $0.01+$ to $0.0,30$ per cont in the subsoil. The phosphorus entent varjex from 0.048 to 0.076 per cent in the surface. and from 0.060 to 0.085 per cemt in the sulsoil. All were high in ralcium, magnesium, and potasium.

\section{Investigation}

The analyes malde ly Robrsion $(59,60)$ show wide valtiation in the sulphur content of different soil types. His investigations, although extemsive, have included only a pat of the numerous soil types found in the Cnited states, so that wher soil tyjes should be analyzed to discover their sulphur as well as their phosphorus content. It is also necesiary to conduct lielel experiments on the difierent soils, as analytical data alone are not sufficient evidence on which to base fertilizer practice. This investigation includes soil analyses and liekl experiments. Soil samples from Indiana, Kentucky, Michigan. (ohio, and Wisconsin were analyzed for phosphorus, sulphur, and volatile matter (losion ignition). Field 
experiments were conducted in Indiana and Kentucky on the fields from which the soil samples were taken.

\section{SOIL ANALYSIS}

Methods of s.urplixg. - The soil samples from Michigan and ()hio (nos. $\mathrm{I}^{-9}$ ) were taken by Dr. William CRocker and those from Wisconsin (nos. IO-II) by Mr. E. H. H.ıL. The samples were taken in the usual way by means of a soil auger. The samples from Indiana and Kentucky were taken when the soil was very wet, and as only the surface soil was sampled, it was believed that more accurate sampling could be done by using a spade or shovel. Some soil was removed to a depth of seven inches, leaving one side of the hole vertical, then a thin slice of soil was cut with the spade to the full depth of seven inches. A narrow strip of this extending from top to bottom was remover for the sample. Three or four such samples from different parts of the field were taken and mixed to form a composite simple. The samples from Indiana were taken by JoHs WOODARD. except no. r 8 , which was taken by Mr. V. G. MiNn, and those from Kentucky by JoHN WoOdARd, except nos. 32-34, which were taken by Mr. J. C. (iextry. All the soil samples were air dried, sifted through a $2 \mathrm{~mm}$. sieve, and thoroughly mixed.

Axilytical metuods. Phosphorus was determined according to the official magnesium nitrate method of the Official Agricultural Chemists. A blank determination was run to determine the possible presence of phosphorus in the chemicals, but no phosphorus was found.

Sulphur was retermined by a modification of the methods of SHEDD and of BRow and KELLocig. In preliminary work it was found that higher results were obtained when the iron and aluminum were removed. In soils low in sulphur the barium sulphate precipitated very slowly, so, at the suggestion of Dr. FREDERICK KосH, ${ }^{\text {IO }}$ cc. of approximately $\mathrm{N}_{1} \mathrm{IO}_{2} \mathrm{HO}_{4}$ was adcled immediately before heating the solution and adding the barium chloride. This sulphuric acid was measured in a burette, and exactly the

I Unpublished work of Dr. FREDERICK Koc H. 
sime quantity of the same aciel was alded to the blank determination, so that subtracting the blank subtracted the sulphur added in the sulphuric aciel as well ats that present in the reagents. In cvery case the 10 ce. Was meatsured between the ro and 20 marks on the burette. Acording to $\mathrm{K}$ (x) h, harium sulphate does not precipitate realily when the concentration of the $\mathrm{S}()_{4}$ ion is low. The aldition of the sulphuric acid is then necessars to bring the concentration of the $S()_{4}$ ion up to the point where precipitation takes place readily. The method as linally adopted is as follows: The equivalent of $10 \mathrm{gm}$. of oren dry soil was weighed into a nickel crucible, moistened with a few dropsi of alistilled water, and part of a weighed $20 \mathrm{sm}$. of sodium peroxide stirred in a little at it time with a nickel rod. If the moisture wits just right, reaction took plate immediately without the application of heat, and the charere was fairly dry by the time most of the sodium peroxide hat been stirred in. If too little water bad been adkled. it was necessary to heat with an alcohol limp to start the reaction. If too much water was added, it was necessiry to heat with the alcohol lamp to bring to the desired degree of elryness before adeling the last of the solium peroxide.) . Ifter the charge was fairly lry the rest of the sollium peroxide wats plated over the charge, the crucible coverexl, and heated over at bunsen burner, raising the temperature grathally to a farrly high temperature which was matintained for an hour. After cooling, the fused mass was removed with hot distilled water to a (100 ec. beaker, neutralized with concentrated HC"l, and then $10 \mathrm{cc}$ additional concentrited HCl adeled. The beaker was then heated for five or six hours on the steam bath with occasional stirring. It was then transferred to a $500 \mathrm{cc}$. flask, covered, and mate up to the mark. The solution was shaken frecpuently for several hours and the $250 \mathrm{ce}$ filtered ofi. The $250 \mathrm{cc}$. of hiltrite wats transferred to a $600 \mathrm{cc}$. beaker, beated on the steam bath, and the iron. aluminium, and silical precipitated with ammonium hrelroxide, allowed to stand a few minutes, and then filtered into a one liter beaker. The precipitate was washed with hot distillex water until the combined filtrate and washings hat a volume of approximately booce. Exatety 10 ce. of approximately I $10 \mathrm{I}_{2} \mathrm{~s}()_{4}$ was then adeled. heated to boiling, aide ro ce. 
of hot io per cent $\mathrm{BaCl}_{2}$ solution adeled a drop at a time from a pipette. The solution was boiled for ten minutes, placed on the steam bath for two or three hours, and then removerl and allowed to stand over night. The barium sulphate precipitate was then filtered off, washer with cokl distilled water, transferred to a weighed porcelain crucible, ignited to a dull red in a muffle furnace, cooled in a desiccator, and weighed. Blanks were determined using the same reagents and adding the same quality of the same sulphuric acid that was used in the determination.

The loss on ignition was determined on samples which had been used for determining moisture. The moisture was determined by heating to gm. of air dry soil in the oven for five or six hours. Part of the samples were heated to $100^{\circ} \mathrm{C}$. in an ordinary oven and part of them to $35^{\circ} \mathrm{C}$. in a racuum oven. After weighing for the moisture determination, the sample was placed in the muffle furnace, heated to a dull red for an hour, cooled in a desiccator, and weighed. The loss on ignition was calculated as pereentage of oren dry soil. Table I gives the results of the analytical work on all the soils analyzed. I'hosphorus, sulphur, and volatile matter (loss on ignition) are reported as percentage of oven dry soil.

Sulphur is present in the soil either in the form of sulphates of calcium, magnesium, and iron, or in the form of organic matter. All the sulphates are quite soluble and are not readily adsorbed, so that they are leached out rapidly and only small amounts are present in the soil. On the other hand, the organic sulphur is insoluble and remains in the soil until oxidized to sulphates. One would expect, therefore, some sort of relation between the sulphur content of the soil and the volatile matter (loss on ignition), which is a rough method of determining the organic matter. The data in table I, however, indicate only a general relation, and that only when samples from the same soil type or closely related soil types are compared. The soil samples from Wisconsin are from the same soil type, but differ in amount of organic matter. There is also a difference in content of sulphur, and the higher sulphur content is found in the sample with the higher content of organic matter. This is true for both surface soil and subsoil. The Michigan 
T.JILE: I

\begin{tabular}{|c|c|c|c|c|c|c|c|}
\hline $\begin{array}{l}\text { Sumpole } \\
\text { nus. }\end{array}$ & $\begin{array}{l}-(1) ! \\
\text { trutat } \\
\text { ituties- }\end{array}$ & 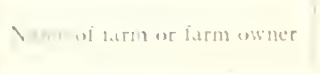 & I.x.t ing: & $\begin{array}{l}\text { Percent.be } \\
\text { of volitile } \\
\text { inter }\end{array}$ & & $\begin{array}{l}\text { rentipe } \\
\text { oulphur }\end{array}$ & $\begin{array}{c}\text { Percentase } \\
\text { of phow } \\
\text { phora }\end{array}$ \\
\hline 1.1 & 7 i. & II:1 here Mer Merfitrm & Mrichigitn & $\therefore 0,-(1)$ & 0 & or 54 & $00 ; 00$ \\
\hline $1 \mathrm{li}$ & -14 & Wah Bee Mee Meefiarm & Mirhigin & $\therefore 3+1$ & 0 & 0157 & 003.30 \\
\hline 1( & $15 \quad \therefore 4$ & II:Ale Bece Mee Mar farm & Michigan & $-(1)^{2}$ & 0 & $0: 16$ & 00,305 \\
\hline$\therefore 1$ & 011 & 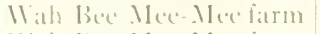 & Mithigan & +145 & 0 & $0.4+(1)$ & 00,511 \\
\hline 213 & $: 14$ & Wals Bice- Mec- Mee litrm & Mi(thigan & $+4 \rightarrow 1$ & 0 & 0.405 & $00,5(1) 1$ \\
\hline 3.1 & 01 & 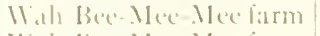 & Michigan & $\therefore x(1) 3$ & 0 & $01 \mathrm{Si}^{3}$ & 00.300 \\
\hline 313 & $\div 1+$ & Wath Bee- Wee Meeditm & Michigran & $=522$ & $\circ$ & 0150 & $\begin{array}{l}0.0324 \\
\text { Iint }\end{array}$ \\
\hline+1 & $2-11$ & With Bee Mee Merefiams & Michiran & $+8(0) 2$ & 0 & 0,361 & $\begin{array}{l}\text { deter } \\
\text { minerl } \\
\text { Sor }\end{array}$ \\
\hline+13 & $\therefore-14$ & Miall-[3er-Mee Meediarm & Mitligirin & $375+$ & 0 & $0211 ;$ & $\begin{array}{l}\text { deter } \\
\text { mined }\end{array}$ \\
\hline 5.1 & 01 & Wale Bee Mee Mee larm & Michirsin & $+i 11$ & 0 & $0 ; 10$ & 00514 \\
\hline 513 & $1+1$ & II:Ah Bee Mee Mee farm & Michigan & 3822 & 0 & 0243 & $0 . f^{(1)}$ \\
\hline 50 & $15-21$ & Math Bere Mer- Meefarm & Michicants & $3 f^{(1)} 2$ & 0 & $01 \pi$ & 00.305 \\
\hline 0.1 & $0(1)$ & I:verctt $:$ farm & ()his) & 31,31 & 0 & 0.3 .32 & $0.078,4$ \\
\hline () 13 & 7 it & Jiverett $:$ firm & () & $=f^{(1)(2)}$ & 0 & 0140 & $0.0+11$ \\
\hline 7.1 & $0<$ & Irnokl $=$ firm & () & 4. $11+2$ & 0 & 0.334 & 007,1 \\
\hline$\because 13$ & $i^{-}$ & Irmolel' $=1$ iarm & (1) & $\therefore(0)+4$ & 0 & 0105 & 00.423 \\
\hline$\because 1$ & 011 & Jacolog farm & (Din & 5228 & 0 & OSरा & 00532 \\
\hline 813 & is & Jacoloy $=1$ & () ) ivio & $31+8$ & 0 . & .0050 & 00.3213 \\
\hline 0.1. & -5 & dit & ()his & $\begin{array}{l}1+325 \\
5000\end{array}$ & 0 & 005 & $00(134)$ \\
\hline 10.1 & $0-1$ & II atrers farm & $\| i_{-10}() \sin$ & 3.110 & 0 & 0,351 & $\begin{array}{ll}0 & 0.7 .43 \\
0 & 0,7.4 .1\end{array}$ \\
\hline Io 13. & $7^{-}$ & Ilager's farm & $11 i_{i}(0) \sin$ & $(0.01) 5.4$ & O. & 0202 & $0.0(1)(6)$ \\
\hline I I . I & 01 & Haterefsirm & 11 isconsin & (1) 8,30 & 0 & 02.45 & $0.0 ; 05$ \\
\hline II & $i$ & llagers farm & isconsin & $+0+3$ & 0 . & $012+$ & 0.04 .77 \\
\hline I $2 \ldots$ & $0-6$ & Rosis farm & littil & 57.58 & 0 . & 0172 & 0.1054 \\
\hline 1,3 & $0^{-1}$ & ( iltr - farm & Inelianat & +721 & 0 . & .0165 & 00024 \\
\hline It.... & 011 & Reroh = litrm & Indianil & $+0,5$ & 0 & 0118 & 0.0 .400 \\
\hline $15 \ldots$ & $0-11$ & $\begin{array}{l}\text { bentleysiatm } \\
\text { (erejped suil) }\end{array}$ & Inclianat & +800 & 0 & 0155 & $0.05(1)$ \\
\hline 16. & 00 & $\begin{array}{l}\text { Bentley farm } \\
\text { (virgin soil) }\end{array}$ & Inclianit & $32+10$ & 0 & 0233 & 0.056 .4 \\
\hline $17 \ldots$ & 0() & Barnete's fitrm & Inclianni & $+\cdot 4^{(1)} 2$ & 0 & $013 ;$ & 0.0402 \\
\hline$I S \ldots$. & 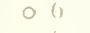 & Mcenllowh farm & Incliana & + So, & 0. & .0155 & $005 \pi$ \\
\hline $10 \ldots$. & $0-0$ & Jetinit firrm & ntucky & $702+$ & 0 . & .0254 & 0.1807 \\
\hline $20 \ldots$ & $0-0$ & Itlina farm & Kentucky & +520 & 0 . & 0232 & 00,00 \\
\hline $2 I \ldots$ & 00 & Ielinat larm & Kentueky & $7 \cdot f(0)$ & 0. & 0131 & 0.10 .30 \\
\hline $22 \ldots$ & $0-(1)$ & Denua larma & Kentucky & t. 584 & 0 . & .0122 & 0.1204 \\
\hline $23 \ldots$ & $0-6$ & Tilina farm & ntucky & 4.315 & 0. & 0200 & $0070 \mathrm{~s}$ \\
\hline $24 \ldots \ldots$ & 00 & Marshall s farn & 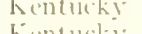 & 7.517 & 0 . & .020 .4 & $01.37 \%$ \\
\hline $2.5 \cdots$ & $01)$ & Downingers latrm & b & $5 \cdot 4^{(30)}$ & 0 & 0150 & 00077 \\
\hline $20 \ldots$ & $0-1$ & $\begin{array}{l}\text { siarm } \\
\text { farm }\end{array}$ & & $\begin{array}{l}5.220 \\
5,320\end{array}$ & 0. & .0230 & 0.1765 \\
\hline $28 \ldots$ & $\begin{array}{lll}0 & 1 \\
0 & 11\end{array}$ & (ientryand Curry fiarm & kentucki. & $\begin{array}{l}3.321 \\
0.0 \geq 1\end{array}$ & $\begin{array}{l}0 \\
0\end{array}$ & $\begin{array}{l}015,3 \\
0315\end{array}$ & $\begin{array}{l}0.13,0 \\
0.2375\end{array}$ \\
\hline 20. & $0-1)$ & Siott $=$ finrm & Kentucky & 5.048 & 0 . & .0235 & 0. 1500 \\
\hline $30 \ldots$ & 00 & Sharl': farm & K(")tuky & (1). 5.10 & 0 & 0101 & 0.1770 \\
\hline $31 \ldots$ & 00 & W(x)rc $:$ farm & kintuek! & 4.723 & 0 . & .0253 & $0.100 \%$ \\
\hline $32 \ldots$ & $0(1$ & linuler s farm & Kentuch! & 5.051 & 0 . & .0250 & 0.1727 \\
\hline 3.3 & $0-6$ & Watt - latrm & Kentu & 5331 & 0 & OI0,3 & 01301 \\
\hline $3+\ldots$ & 0.4 & lomeng $=$ lasm & liy & 11.105 & 0 & 0313 & $0.3+07$ \\
\hline
\end{tabular}


soil samples are also quite similar in texture. Here again we find a high sulphur content with a high organic matter content, and a low sulphur content with a low organic matter content. When we compare dilierent soil types or samples from the same type but from fields which have been cropped differently, however, there is little evidence of any relation. Samples $7 \mathrm{~B}$ and o $\mathrm{B}$ have approximately the sime sulphur content, yet the volatile matter in the latter is twice that in the former. Both these samples are subsoils from Ohio, and were taken from fields that were not far apart, but 7 B is on upland silt loam while 9 B is a muck soil. Again, the cropped soil (no. I5) and the virgin soil (no. Io) from Bentley's farm, Indiana, differ only slightly in volatile matter, but differ widely in sulphur content. Gentry and Curry's soil (no. 28) has shightly less volatile matter than sharp's soil (no. 30), but considerably more sulphur. Sample io A from Wager's farm in Misconsin is a fine sandy loam soil with very little clay but a large amount of organic matter, as may be recognized by its black color, yet it contains considerably less sulphur than sample 2 A from the Wah-Bee-Mee-Mee farm in Michigan, which is also a sandy loam soil, containing considerable coarse sand with sufficient organic matter to give a black color.

It seems, then, that from the sulphur standpoint, as well as the nitrogen standpoint. the character of the organic matter is of more importance than the amount. Sulphur, like nitrogen, is mainly present in the proteins, so that a small amount of high protein organic matter, such as one woukl obtain by plowing under legumes. would be more valuable than a larger quantity of organic matter from wheat or oat straw or cornstalks. It seems probable also that the proteins are more readlily decomposed than the nonprotein organic matter, so that the sulphur and nitrogen would be oxidized more rapidly than the carbon, and the sulphur and nitrogen content might become quite low when there was still a considerable amount of carbonaceous organic matter in the soil.

In all the simples analyzed, the sulphur content was less than the phosphorus content. One of the samples from Ohio which was taken in a low wet place was a muck, very high in organic matter. 'This soil harl nearly as much sulphur as phosphorus in 


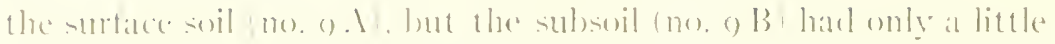
more than half as much sulphur as phosphores. The difledence between the -ulphur and phospluerus contents in one of the Michigan soils wats not sreat. 'The suriase seil (no. 2.1 ) contained O.Ofiso pere cent suphur and 0.0518 ger cent phosphorus, while the

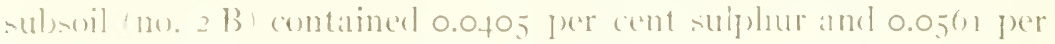
cent phesphorus. Ill the other samples were much higher in phosphorus than in sulphur. The difierenes was veryegreat in one of

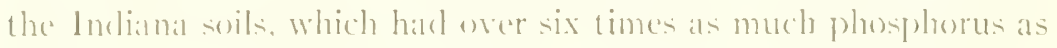
sulphur, and in the Kentucky soils, in most of which the phosphorus contemt was from five to eleren times as much ats the supplur. In two of the Kentucky solit the phospluorus content was only thee times ats much as the sulphur, and in one only four times as much.

The Michigan soils, samples 1-5. Were taken on the Walh-BeeMee Mee farm at White l'igeom, Michigan. Samples a and 5 were sampled to three depthe and all the others to two depths. 'There soil ate alluvial sandy loams, varying from light brown to dark hrown on the surface and grateling into a yellow simely subsoil contaiming some sravel. The light colored simples contained more simel in both surlace and subsoil and were lower in volatile matter, sulphur. and phosphorus, than the darker colored ones. 1ll were low in both sulphur and phosphorus. but the sulphur is lower than phosphorus in all the samples. With the exeeption of sample $x$, the sulphur was always lower jin the subsoil than in the suriace soil.

The ()hio soils, simples $6-0$, were taken neall (opley, (Ohio. Nos. 6. 7. and $S$ are upland silt loams containing some simd. The surface soil is a vellow brown gradeng into a uniformly light yellow subsofl, which indieates good underdrainare as well as good surface drainage. These soils apparently letong to the type mapped as the Wooster silt loam. The sulphur content was low in both surfice and subsoil, while the phosphorus content was fairly good in the surface but low in the subsoil. In every sample the subsoil was lower in volatile matter, sulphur, and phosphorus than the corresponding surfice soil.

Sample o is peorly drained, and the surface soil has a large amount of organic matter with some silt, sand, and a little claý. 
The subsoil has much less organic matter, but the proportion of its other constituents is about the same as in the surface. The surface soil is very high in volatile matter, sulphur, and phosphorus, while the subsoil is very low in both sulphur and phosphorus.

The Wisconsin soils, samples io and I t, are from near Beloit, Wisconsin. They are fine sandy loams, dark brown on the surface and a lighter brown in the subsoil. In both samples the volatile matter, sulphur, and phosphorus are higher in the surface soil than in the subsoil. The sulphur content is low in both surface soil and subsoil in both samples, but the phosphorus is good in the surface soil of both samples, fair in the subsoil of sample ro, and poor in the subsoil of sample Ir. Both sulphur and phosphorus are lower in the subsoil than the surface soil in both samples.

The Indiana soil samples (nos. I 2-rS) were taken near Charlestown, Clark County, Indiana. This region is underlain by limestone rock, but the rock has been covered by a thick layer of windblown material, from which most of the soils were formed. All the soils sampled were formed from this windblown material except no. I2, which was taken on the blutf of a small stream where there was considerable erosion. It seems that the erosion has removed the greater part of the windblown material, and to a large extent the soil is formed from the underlying limestone. This is probably the reason why this sample resembles in gencral appearance and in chemical composition the Kentucky soils rather than the adjacent soils from the windblown material or loess. Sample 12 has a light brown silc loam surface soil grading into a reddish yellow subsoil. Like the other Indiana soils, the volatile matter and sulphur are low, but the phosphorus is high like most of the Kentucky soils.

The loessal soils include two types, the one with good natural underdrainage and the other with poor drainage. The former, which includes samples $15^{-1} 8$, is a yellow gray silt loam in the surface soil and a yellow silt loam in the subsoil. The latter, which includes samples $x_{3}$ and 14 , has a gray or slightly yellowish gray silt loam surface soil underlain by a gray or gray and yellow mottled silt loam subsoil. Both are poorly drained, but sample r, is more nearly level and has more gray color in both surface and subsoil. All the samples from both types are low in volatile matter, sulphur, 
amel phosphorus. Samples y 5 and 10 were taken a few rods apart, the fomer from a field which hat been in alfalla for several years, and the batter from virgin lind. Buth have practically the same phosphorus content, but the sulphur is much higher in the virgin $\therefore$ (oil.

All the soil simples irom Kentucky (nos. ro-3t) are resiclual limestone soils, but no. it was derived from the Trenton limestone, which is high in phosphorus, while the others are all from the Cincinnati limestone, but no. 2s was taken from soil derived from (oncinnati limestone, but it was only a short listance from the division line between the ( incinnati and Trenton formations, and had probably received some material from the 'Trentom formation. Samples 1027 are from Matsom (ounty. while simples 28 3t are from Mercer county. Simples so and 2 r are clay loams, while 20 and 2227 are silt loams. All are light brown to grayish brown in color. Simple 3t is a heary clay loam, sample 28 is a heary silt loam or light clay loam, while samples 20 3.3 are silt loams. Samples 3 I and 3.3 are quite gray in coler, and 3.3 contains iron concretions. No. 3i is known locally as white oak lanel, and both are recognized as poor soils. Nll the other samples are light brown (xeept no). 3t, which is a gritgish lorown. All the Kentucky soils are low in volatile matter execet the clay loams. in which part of the volatile matter is probably water of combination. All are low in sulphur, no. 3t heing the only one above 0.03 per cent. This sample is from the 'Trenton formation and contains many unweathered fragnents of limestone. It is posible that the sulphur content as well as the phosphorus content of the Trenton limestone may be ligher than in other fommations. No. 3t contains $0.3+07$ per cent of phosphorus, which is eleven times as great as the sulphur content. 'This is much higher than any of the others, but all the others are high in phosphorus.

RELATION BETWEEX AMOLNTS OF SLLPHLR AND PHOSPHORLS

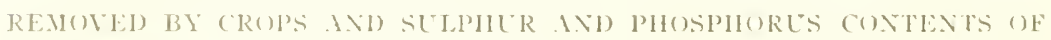
solds. - I better ideat of the supply of sulphur and phosphorus in the soil can be ohtamed if the pounds per acre of these elements found in the surfate soil is compared with the amounts removed by some of our common crops. Table II grives the amounts of sulphur 
and phosphorus removed by some of the common crops. The yields per acre and the amounts of phosphorus removed by these yields are taken from Hopkins and PetTit's (34) table, while the amounts of sulphur removed are computed from HART and Peterson's analyses.

As pointed out by Hopkins and Pettit (34), these yields are exceptionally large, but they have been obtained by some farmers, and others may obtain them under proper systems of farming. If, however, smaller yields are removed, it will not prevent soil depletion, but will only delay soil exhaustion if the elements removed

T.BLE II

POUNDS PER ACRE REMUNED BY FARM CROPS

\begin{tabular}{|c|c|c|c|}
\hline \multirow{2}{*}{ CROP } & \multirow{2}{*}{ JiELD PER ACRE } & \multicolumn{2}{|c|}{$\begin{array}{c}\text { PUUNDS PER ACRE REMOVED } \\
\text { ANNUALIY }\end{array}$} \\
\hline & & Sulphur & Phosphorus \\
\hline 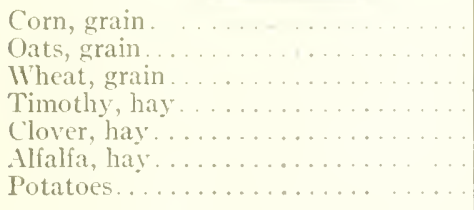 & $\begin{array}{l}100 \text { bushels } \\
\text { Joo bushels } \\
50 \text { bushels } \\
3 \text { tons } \\
+ \text { tons } \\
8 \text { tons } \\
300 \text { bushels }\end{array}$ & $\begin{array}{r}7.8 \\
5.8 \\
5.1 \\
11.4 \\
13.0 \\
40.0 \\
24.7\end{array}$ & $\begin{array}{r}17.0 \\
11.0 \\
12.0 \\
9.0 \\
20.0 \\
36.0 \\
13.0\end{array}$ \\
\hline
\end{tabular}

are not returned in some form. In actual practice, failure to return to the soil the elements of plant food which are removed in the crops will result in a gradual decrease in yields, so that the amounts of plant food removed will gradually become less. It is impossible to determine the time when complete exhaustion will take place, but a comparison of the amounts of plant food removed by large crops with the amounts present in the soil will emphasize the importance of renewing the supply in the soil before the soil supply is reduced below that necessary for satisfactory crop yields. Table III gives the pounds per acre of sulphur and phosphorus in the surface soils analyzed and the number of years' supply of each for several common farm crops, if maximum crops are removed, such as are given in table II.

Table III shows that all the soils are too low in sulphur to grow alfalfa for 40 years, while 22 of them have phosphorus enough to 
grow alfalia to years or longer, provided, of course, none of these elements is alded in any way and none removed except in the crops. Sample 9.1, which hats the highest sulphur content, has sulphur

T.\BI, I: III

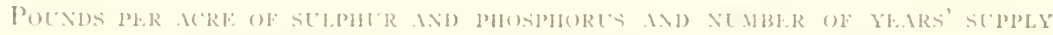

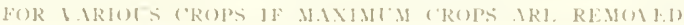

\begin{tabular}{|c|c|c|c|c|c|c|c|c|c|c|c|c|}
\hline \multirow{3}{*}{ S.II so. } & \multicolumn{6}{|c|}{ SWLAHIR } & \multicolumn{6}{|c|}{ I'HOSPHORTS } \\
\hline & \multirow{2}{*}{ 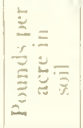 } & \multicolumn{5}{|c|}{ 1o. of years' supply for } & \multirow{2}{*}{ 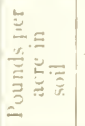 } & \multicolumn{5}{|c|}{ No. of years' supnly for } \\
\hline & & Sorn & Whe:t & Timo- & ('over & Mfalfa & & Corn & Wheat & Timo- & Clover & Llfalfit \\
\hline 1.1 & 310 & .10 & 02 & 25 & 2.4 & 7 & $7 \geq 0$ & +12 & 1,0 & to & $3^{1)}$ & 20 \\
\hline 2.1 & (1) 72 & 12.5 & 101 & $S_{5}$ & 7.5 & 21 & 10.30 & O $\mathrm{I}$ & $S()$ & 115 & 52 & 20 \\
\hline 3.1 & $i(n)$ & $4 i$ & 72 & 30 & 23 & $S$ & 730 & $t^{\prime \prime}$ & 0,3 & $x_{3}$ & 39 & 22 \\
\hline .1. & 722 & 0.3 & 1.42 & (1) 3 & 50 & 16 & & & & & & $\ldots$ \\
\hline 5.1 & $6,3,4$ & 82 & 125 & 56 & 40) & 11 & $102 x$ & 110 & 80 & IIf & 51 & 20 \\
\hline i. 1. & $4(1.4$ & 10 & () I & +1 & 30 & 10 & 1570 & () 3 & 1.31 & 1,5 & 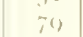 & +4 \\
\hline 7.1 & $a x$ & $S()$ & $1.3 \mathrm{I}$ & tio & 51 & $1+4$ & $1.7+2$ & () 1 & 12() & 175 & 77 & +3 \\
\hline$\therefore 1$ & $5(1) 2$ & 72 & I10 & 50 & 43 & 12 & 110.4 & 0,8 & (1) 7 & 120 & 54 & 32 \\
\hline 0.1 & 1310 & 2.32 & 355 & 150 & 1.30 & 30 & 1874 & 110 & 150 & 200 & (1) 4 & 52 \\
\hline 10.1 & 702 & () 0 & 136 & 02 & it & 15 & 1458 & 8.8 & 124 & 10,5 & 74 & 41 \\
\hline I I . $1 \ldots$ & $4(10$ & 6.3 & (s) & +3 & 3 & 11 & 1500 & 04 & 1.3 .3 & $17 \pi$ & so & 4.4 \\
\hline$I 2 \ldots \ldots$ & 34.4 & 47 & 17 & 30 & 20 & 7 & 2105 & 124 & 170 & 234 & 105 & 59 \\
\hline $1,3 \ldots \ldots$ & 3,30 & 42 & 0.5 & 20 & 25 & 7 & $12.5(1)$ & 74 & 105 & 130 & 0,3 & 35 \\
\hline 14 & 2.30 & 30 & fi) & 21 & I & 5 & ()io & $5 \hat{i}$ & 82 & 100 & 4) & 27 \\
\hline $15 \ldots \ldots$ & 310 & 40 & (i) 1 & 28 & 24 & $i$ & 11,32 & 07 & 04 & 126 & 57 & 31 \\
\hline I $(1) .$. & $f(0)$ & 10 & ()) [ & 41 & 36 & 10 & 1124 & (i) & 0.1 & 125 & 50 & $3 \mathrm{I}$ \\
\hline $17 \ldots \ldots$ & $3(0)$ & 47 & $\pi 2$ & 32 & 28 & 8 & 0.1 .1 & 5i) & $\$ 2$ & 100 & fo) & 27 \\
\hline 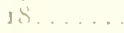 & 310 & 10 & (1) & 25 & 24 & 7 & 11.50 & os & ()) & I 2is & in & 32 \\
\hline $10 \ldots \ldots$ & 510 & (1) & 101 & 4.5 & 40 & 11 & 3704 & 223 & 310 & 422 & 100 & 105 \\
\hline $20 \ldots$ & $f^{2}+4$ & 10 & (1) $\mathrm{I}$ & +1 & 36 & 10 & $15(0)$ & 0.4 & 133 & 177 & so & 4.4 \\
\hline $21 \ldots$ & $20) 2$ & .34 & 51 & 2.3 & 20 & () & 3272 & 1022 & 273 & 30.4 & 16.7 & () $\mathrm{I}$ \\
\hline$\therefore 2 \ldots$ & 2.44 & 31 & $4^{4}$ & 22 & IO) & 5 & 2500 & 15.3 & 216 & 288 & 1.30 & $i^{2}$ \\
\hline $2.3 \ldots$ & +12 & 5.3 & 85 & 30 & 32 & ()) & 1530 & 00 & $12 S$ & $17 \mathrm{~J}$ & 77 & 43 \\
\hline $24 \ldots$ & 528 & 28 & 10.1 & . 6 & 41 & 11 & 27.54 & 102 & 2,30 & .306 & 133 & 77 \\
\hline $25 \ldots$ & 318 & 41 & 0.4 & 28 & 24 & $\overrightarrow{7}$ & 103.4 & 115 & 10,3 & 210 & os & 54 \\
\hline 20 . & 472 & (1) & 0.3 & 41 & it) & 10 & 3530 & 20.3 & 204 & 3) 2 & 177 & 0.8 \\
\hline $27 \ldots$ & 306 & 30 & .50 & 27 & 24 & 7 & 2740 & 101 & 228 & 304 & 137 & 76 \\
\hline 25. & 400 & 3 & () & 4.3 & 38 & I I & +710 & 277 & 30,3 & 523 & 236 & 1,31 \\
\hline 20) & 470 & 10 & () 2 & +1 & 30 & 10 & 3000 & 17() & 250 & 333 & 1,50 & 83 \\
\hline 30 & 322 & $4 i$ & 0,3 & $2 S$ & 25 & 7 & 35.54 & 20() & 200 & $3(5)$ & $1-5$ & 90 \\
\hline $3 \mathrm{I}$ & 500 & 0.5 & (i) & 44 & 30 & 11 & 2014 & 113 & $1(1)$ & 224 & 101 & 56 \\
\hline 32. & 500 & 0.4 & (1): & 44 & 38 & I I & $3+5.54$ & 203 & $2 \times 5$ & 354 & 17.3 & () 6 \\
\hline 33. & 320 & 42 & 0.4 & 20 & 25 & 7 & 2612 & 154 & $2 I S$ & 200 & 131 & 7.3 \\
\hline & 020 & so & 122 & 55 & 45 & 14 & 0.514 & 401 & $5(x)$ & 757 & $3+1$ & I Sio \\
\hline
\end{tabular}

enough for 39 years of altalfa and phomphorus enough for 52 years of alfalfa. (Only one other soil, no, 2 1, hal enough sulphur for 20 years of alfalfa, while three soils, nos. I9, 28 , and 34 , have enough 
phosphorus for ioo or more years of alfalfa. No. 34 has phosphorus enough to grow alfalfa i $S_{9}$ years, but sulphur enough for only it years. The phosphorus content of no. 28 is sufficient to grow alfalfa for I 3 I years, but the same crop would deplete the sulphur in I y years. All these soils have sufticient phosphorus to grow maximum yields of alfalfa for 20 years or longer, while all but two would be depleted of sulphur in less than 20 years.

Of the other crops mentioned, corn, wheat, and clover remove smaller amounts of sulphur than phosphorus; while timothy, like alfalfa, removes more sulphur than phosphorus. Timothy, however, removes only about one-fourth as much sulphur, and onefourth as much phosphorus as alfalfa, so that the supply of each would last correspondingly longer, yet soil git is the only one that carries sufficient sulphur for 100 crops of timothy. Soil 9.1 has sulphur enough to grow timothy i 59 years, clover I 39 years, corn 232 years, and wheat 355 years. No. 34 has phosphorus enough for for corn crops, 508 wheat crops, and 34 I clover crops; yet the sulphur would be depleted by So corn crops, I 22 wheat crops, or 48 clover crops. The lowest phosphorus content is in soil I A, a sandy loam soil, which has 720 pounds of phosphorus in the surface 7 inches of soil. The phosphorus in this soil would be depleted by growing corn 42 years, wheat 60 years, timothy so ycars, clover 36 years, or alfalfa 20 years. In the same soil the sulphur would be removed by 40 years of corn, 62 of wheat, 28 of timothy, 24 of clover, or 7 of alfalfa.

Table III shows the importance of both sulphur and phosphorus if maximum crops of legumes, particularly alfalfa, are to be grown. It also shows that, in most soils, sulphur is more likely to be deficient than phosphorus. It does not take into account the leaching of these elements from the soil, which is practically nil in the case of phosphorus and very high in the case of sulphur; nor the supply in the rain water, which is nil in the case of phosphorus and may be quite high in the case of sulphur near cities in the humid regions. Whether the amount of sulphur lost in the drainage water exceeds that gained in the rain water is still unknown. It is certain that the amount of leaching will vary with the character of the soil, the rainfall, and the character of the plant growth. The amount of 
sulphur in the rain water will vary with the rainfall and the neatrness (1) cities where larere amounts of solt coal are used. It is persilste that, in some places under certain conditions, the amount of sulphur brought down in the rain water will expual or exceed that lost in the drainatere, but that in other places and under other conditions the losis will exceed the gain. Iivele experiments atre needed to see whether the plants will respond to sulphur fertilization under ficlel conditions. Remarkable responses were obtained by JuDGE

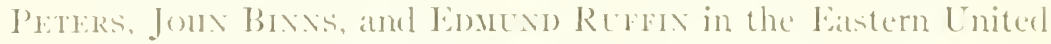
Sitates ('RockER, I5), and have recently been obtilined on the

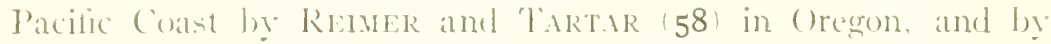
(OLSON 54 in Washingtom. 'Tos secure further information along this line, cooperative experiments were conducted on some farms in Indiana and kentucky from which some of the samples reported in table I were taken.

\section{('OOPIRATIVE FIELI) EXPERIMENTS WITI GYPSUM}

'The ficle experiments were conducted in cooperation with the film owners. The farm owners were to alply gypsum and report on the effect on yields, if amy. Some of the fanners falled to make any report, and those who did gave no weights, so that the results are not as satisfactory as could be desired. Results reported are as follows.

In the Indiana experiments, gypsum wats applied to allialfa, red clover, and tobacco. The only report received was with regard to the tobacco. This tolbaceo field was on the farm of Mr. Ross, southwest of Charlestown, Indiana. This is the field from which sample I 2 was taken, and, as shown in tables I and III, is low in supphur and high in phosphorus. Mr. Ross reports a marked increase in yiclel of tobaceo from the use of gypsum on this fiedel, but gives no quantitative datal.

Gyjoum was applied to alfalfa, red clover, sweet clover, and tobaceo in Matson ('ounty, hentucky. 'The crops were injured so batly by weat her conditions, howerer, that no results were obtained.

In Mercer (ounty, hentucky, gypsum was applied to tobacco, clover, and alfalla. Of the famers responding, Mr. Sinarp reported no increase in tobacco, while Mr. FowLER rejorted an increase in 
the second clover crop, and Mr. Tuomer an increase in alfalfa. Neither of these men weighed the hay, so the results are not quantitative. Mr. SHarp's fiekl, from which sample 30 was taken, is low in sulphur and high in phosphorus, but it showed evidences of being farmed hard, and was evidently low in nitrogen, which was probably the limiting element for a non-leguminous crop like tobacco. Mr. Fowler's soil, no. 32, has 0.0250 per cent sulphur and 0.1727 per cent phosphorus, equivalent to 500 pouncls of sulphur, and 3454 pounds of phosphorus, in the surface soil; so sulphur was probably the limiting element for clover. Mr. Tuoner's field, sample 34, had 68I4 pounds of phosphorus, the highest of the samples analyzed. This sample also contained small fragments of limestone, so that there was an abundance of lime. On the other hand, the sulphur content, 626 pounds, although higher than in many samples, is probably rather low for a plant like alfalfa, which uses such large quantities of sulphur.

These results are not conclusive, but it seems probable that sulphur may be a limiting element on some of these soils, and that gypsum is a satisfactory source of supply for this element. More field experiments are necessary in the humid part of the United States, and great care in conducting these experiments is necessary if satisfactory results are to be obtained. Experiments should be conducted through several years to avoid weather conditions, which may be the limiting factor in some years. On some soils drainage is necessary, and no fertilizer treatment will have any effect until this is done. Most soils in the humiel part of the United States are acid. A large part of them are so acid that liming is necessary before any other treatment is effective, especially for leguminous crops. Table I shows a high phosphorus content in some of the soils reported in this paper, but those are exceptional soils. Is a general rule soils are deficient in phosphorus, and fanmers report increases in crop yields for the use of acid phosphate. It is impossible, however, to tell how much of the increase is due to the phosphorus and how much to the sulphur in the acid phosphate. A comparison of acid phosphate with rock phosphate and gypsum, and with gypsum alone, and rock phosphate alone would give some valuable results. 
Many of the lllinesis experiment fieds include three check plots in each series. These cheek plots are all untreated and are only at short distance aljart, yet some of them differ widely in crop vicels. It is reationahle to assume that neighlooring plots receiving the same fertilizer trattument would differ as widely. These differences due to factors not under the control of the investigators make the probable error large, and when only one plot of each treatment is used, the differences between plots with different treatments must be great before one can assume that the treatment has been effective. Where the differences are ats great as in the work of Remer

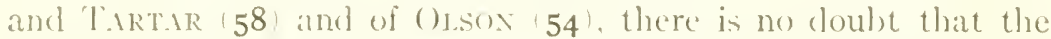
treatment hat been effective. but in many of the field experiments in different parts of the country the differences are too small to justify the conclusions (lrawn from them, as the probable error is so great. Where a number of plots of each treatment are used, the uncontrollable factors tend to neutralize each other and the probable error is reduced. Is the number of plots of catch treatment increases, smaller arerage differences are necessary to be significant. It secms probable that three plots of each treatment are necesary if satisfactory results are to be obtained. In the past investigators have had a tenelency to seatter fiedel experiments over a number of widely separated fields on the same soil type. It seems probable that more satisfactory results would be obtained if the work were confined to one fiedel on each soil type, and each field had from three to live plots of each treatuent.

\section{Summary}

I. Composite soil samples from Indiana, Kentucky, Michigan, ()hio, and Wisconsin were analyzed for total sulphur, total phosphorus, and volatile matter (loss on ignition), and cosperative fertilizer experinents with aglom were conducted in fiedes in Indiana and Kentucky.

2. 'The analytical clata show at general relation between the sulphur content and loss on ignition in soil simples from the same soil type or closely related soil tyes, but the relation is not apparent when different anil yyes are comprared. 
3. The sulphur contents in the surface soil vary from o.o I $\$$ to 0.0905 per cent, while the phosphorus contents vary from 0.0360 to 0.3407 per cent. All the upland soils and most of the alluvial soils are low in sulphur. Most of the Kentucky soils and one of the Indiana soils are high in phosphorus. This is undoubtedly due to the influence of the rock from which the soils were formed, as all the Kentucky samples were from soils derived cither from the 'Yrenton limestone or the Cincimnati limestone, both of which are high in phosphorus content.

4. The sulphur and phosphorus contents were catculated to pounds per acre in the surface soil, and compared with the amounts of sulphur and phosphorus removed by miximum crops of com, wheat, timothy, clover, and alfalfa. The highest sulphur content is sufficient for only .39 years of alfalfil, I.39 of clorer, I 59 of timothy, 355 of wheat, or 2.32 of corn; while the lowest sulphur content is sufficient for only 5 vears of alfalfal, is of cloter, 2 I of timothy, 46 of wheat, or 30 of corn. The lowest phosphorus content is equal to the amount removed hy 42 years of corn, 60 of wheat, So of timothy, 36 of clover, or 20 of alfalfa. On the other hand, it woukl take 40 r years of com. 508 of wheat. 757 of timothy, it of clover. or 189 of alfalfit to remove as much phosphorus as is found in the soil with the highest phosphorus content.

5. On some of the soils tobacco, clover, and alfalfa have been benefited by the use of gypsum. The results, however, are not quantitative. Nore fiekl experiments are needed and greater care should be taken to eliminate other factors as far ats posibible. Fach treatment shoukl be replicated to reduce the probable error.

This investigation was conducted under a research fellowship from the Gypsum Industries Issociation. The work was perfonmed at the University of Chicago in the Hull Botanical Laboratory under the direction of I)r. Willam ('Rorker. The author wishes to thank the Gypsum Industries Association for their kindness in fumishing the fellowship and Dr. CROCKER for his kind and helplul advice and criticism. Thanks are also due I)r. Frederick KucH for his kind advice and criticism of analytical methods.

LNINERSTYY of ILLiNoIS

URB.ANA, lLL. 


\section{ITTER.ITLRE (TITEI)}

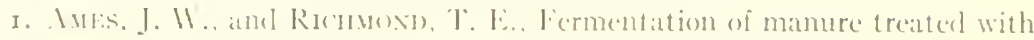
sulphur and sulphates. ("hauges in nitrogen and phosphorus content. soil sicience $4:-7)$ Sis. 1017.

2. Liffect of sulpholication and nitrification on rock phosphate. Suil sicience $6: 351,30.4 .1018$.

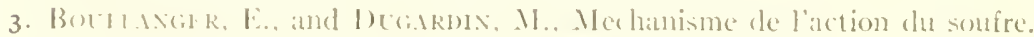
('ompt. Rendl. Acall. sci. P'aris $155: 327-320$. 1012.

4. BRenter, C. E., The reaction of lime and gypsum on some Oregon soils. Jour. Ind. anel Engin. ('hem. 2:520-5,30. 1010.

5. BREZIEUI. J.F.. and BRIGGS, L.J.. Concentration of potassium in orthoclise solutions not a meatsure of its availability to wheat seedlings. Jour. Agric. Res. 20:01, -621. 1021.

6. BRtidis, L. J., and BREZRALE, J. F.. Availability of potash in certain orthoclase bearing soils ats affected by lime or gypsum. Jour. Igric. Res. 8:21 2S. IO) I T.

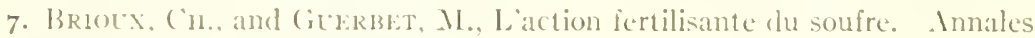
sci. Igron. $30: 305-300.1013$.

8. Brooks, II. I'. Mlfalfa. Matss. Igric Exp. Stat. Bubl. 154. 1914 (p. 158).

9. - - I'hosphates in Massalchusetts agriculture, importance, selection, and use. Mass. Mrric. Exp sta. Bull, 162.1015.

I0. BRowx, P. E.. and (iwixy, A. R., Effect of sulphur and manure on availalbility of rock phosphatte in soil. Iowa Igric. Exp. Sta. Res. Bulb, 43: $373-370.1017$.

I I. Browr, P'. L... and Kendogg, E. H., Sulpholication in soils. lowa Agric. Exp. Stat, Res, Bull. i8:104-110. I014.

I2. BRoWX, I'. E., and WARNR, H. W'. The production of available phosphorus from rock phosphate by composting with sulphur and manure. Soil science 4:260-2\$2. 1917.

13. Browate. J. W., The fiekl book of manures or the Imerican muck book. $185+(p p \cdot 68-75)$.

I4. Bruckiter, W. II., Imerican manures. 1872 (p. 65).

15. Couckler, Ilu., Ilistory of the use of gypsum as a fertilizer. (Unpublisherl article.)

I6. DEuobor, M. 1. Recherches sur l'action fertilisante du soufre. Compt. Rentl. Acall. Sci. Paris 156:725-728. 1013.

17. 1)ter., F. L., The relation of sulphur to soil productivity. Jour. Amer. soc. Agron. 8:154-100. 1916.

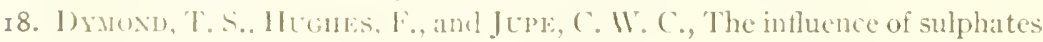
at manures upon the yidel and feeding value of crops. Jour. Agric. Sci. I: $217-220.1905$.

19. EATux, ‥ V., Sulphur content of soils and its relation to plant nutrition. (Cinpublished article.) 
20. Ellett. II. B., and Harris, II. G., Cooperative experiments for the composting of phosphate rock and sulphur. Soil sicience, ro:315-325. I0 20 .

2r. Feilitzen, H. von, Úber die Verwendung der Schwefelblüte zur Bekämpfung des Kartoffelschorfes und als indirekes Düngemittel. Fühling's Landw. Zeit. 62:230. I913.

22. FraPs, G. S., The effect of additions on the availability of soil potash, and the preparation of sugar humus. Texas Igric. Exp. Sta. Bull. I00. I-30, IOI6.

23. Fred, E. B., and HART, E. B., The comparative effect of phosphates and sulphates on soil bacteria. Wis. Agric. Exp. Sta. Res. Bull. 35. pp. 42-44. I91 5 .

24. Greaves, J. E., Carter, E. F., and Goldthorpe, H. C., Influence of salts on nitric nitrogen in soils. Jour. Agric. Res. I6:107-135. 1919.

25. (iRjffirhs, A.B., A treatise on manures. ISS9 (pp. 247-248).

26. HALL, A. D., Book of Rothamsted experiments. I9I7.

27. Hart, E. B., and Peterson, W. H., Sulphur requirements of farm crops in relation to the soil and air supply. Wis. Agric. Exp. Sta. Res. Bull. no. I4. IOII.

28. - - Sulphur requirements of farm crops. Jour. Amer. Chem. Soc. 33:549. IOII.

29. Hart, E. B., and Tottingham, W. E., Relation of sulphur compounds to plant mutrition. Jour. Agric. Res. 5:233-248. I915.

30. Heinrich, R., Concerning the conservation of manure. E.S.R. 5:329, 330. IS93-IS94. Abst. from Landw. presse 20:\$25. IS03.

3r. Hilgard, E. II., Soils; their formation, properties, composition, and relation to climate and plant growth. 1006 (p. 43).

32. Hopkiss, C. G., Soil fertility and permanent agriculture. igio (pp. 39, $\left.18_{9}\right)$.

33. Hopkixs, C. G., Mosier, J. G., Pettit, J. H., and Rendhimer, J. E., Hardin County soils. Ill. Agric. Exp. Sta., Soil Report no. 3. I9I2.

34. Hopkins, C. G., and I'Ettit, J. H., The fertility in Fllinois soils. Ill. Agric. Exp. Sta. Bull. no. I 23. IgoS (pp. 533-535).

35. Hunt, Thos. F., Soil fertility. Pa. State Coll. Bull. no. 9o. Igoo.

36. Lawes, J. B., and Gilbert, J. H., Report on the growth of red clover by different manures. Jour. Roy. Agric. Soc. 21:194. IS60.

37. Liebig, J. vos, Principles of agricultural chemistry. $1 \$_{55}$. Transl. by Wy. Gregori, p. 99.

38. List, H. C., The influence of sulphur on soil acidity. Jour. Ind. and Engin. Chem. 6:747. 1914.

39. Lipman, C. B., and Gericke, W. F., Does calcium carbonate or calcium sulphate treatment affect the solubility of the soil constituents? Univ. Calif. Publ. Agric. Sci. 3:271-282, I918. 
40. The sisnificance of the sulphur in sulphate of ammoniat applieet to

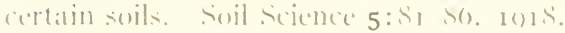

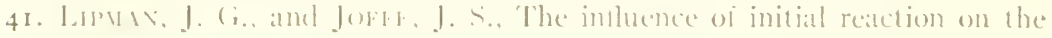
oxidation of sulphur and the formation of atralable phosphates. Soil Silin)(\% $10: 327-3,32.10) 20$.

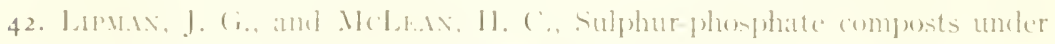

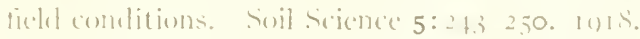

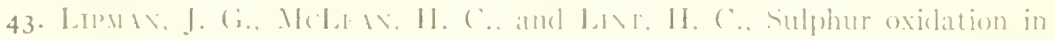

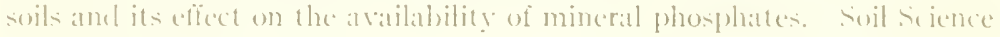
$2:+(0) 5-3,3 \cdot 1010$.

44. Lows. T. L., and Brate1, J., Lysmeter experiments. ('ormell Inis:

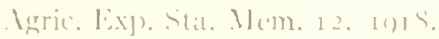

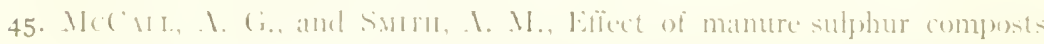
upon the atritability of the potalsium of greensatnels. Jour. Igric. Re's. I $9: 230) 25,10.1(1) 20$.

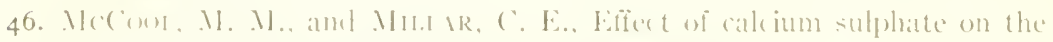

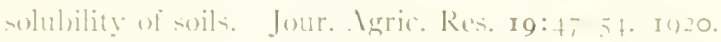

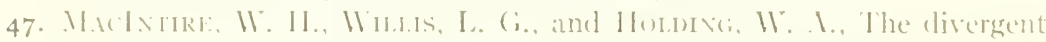
eflects of lime and magnesia upon the conservation of soil sulphur. Suil sicince $4: 231 \quad 237.1017$.

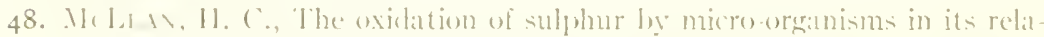

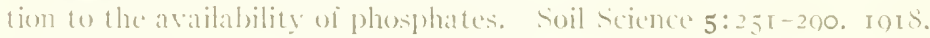

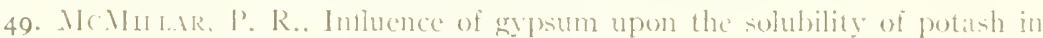
soils. Jour. Igric. Res. I4:01-66. 10) Is.

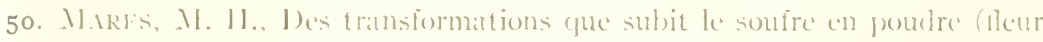
(le soufre et soufre trituré) yuand il est réprandu sur ke sol. (ompt. Rend.

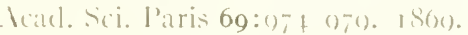

51. Mnt.ter, 11. (i., Sulphates alfecting plant growth and composition. Jour. Igric. Ro's. I $7: \$ 7-101,1010$.

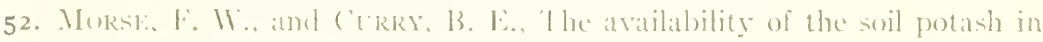

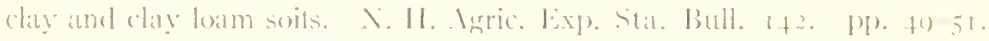
j() () ().

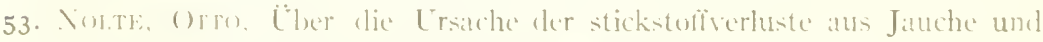
stalkmist. Latmetw. Vors. Stat. 96:300) 324. 10)20.

54. ()1sts, (ise. 1. Cnpublisher work of the Chemistry Department, Washington stitte (i)llege.

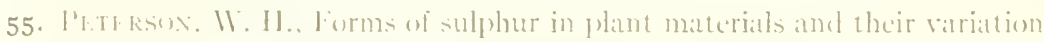
with the soil supply. Jour. Imer. ("hem. Sex. 36:1200-1300. 1014.

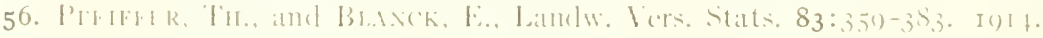

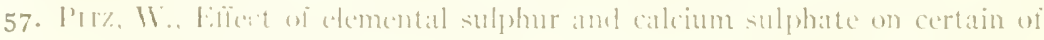
the higher and lower forms of phant life. Jour. Igrice. Res. 5:-7-7-so. 11)! ?.

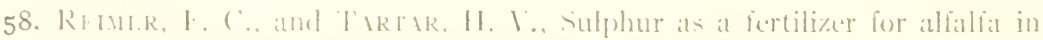
southern ()regonn. Ore Igric. lixp. Sta. Bull. 16,3. 10)10. 
59. Robinsox, II. O., Inorganic composition of some American soils. IT.S. Dept. Agric. Bull. I22. I9I4.

6o. Robinson, IW. O., Steinkonig, L. A., and Fry, W. H., Variation in chemical composition of soils. U.S. Dept. Agric. Bull. 55 I. I9I7.

6r. Schreiner, O., The rôle of oxidation in soil fertility. U.S. Dept. Agric. Soils Bureau Bull. 56. Pp. 30-42. I900.

62. SHEDd, O. M., The sulphur content of some typical Kentucky soils. Ky. Agric. Exp. Sta. Bull. I7t. Ior3.

63. - - Effect of sulphur on different crops and soils. Jour. Agric. Res. II:OI-IO3. IOI 7 .

64. Sherbakoff, C. D., Potato scab and sulphur disinfection. Cornell Univ. Agric. Exp. Sta. Bull. 350. 738, 730. 1014.

65. Simtin, R. S. Some effects of potassium salts on soils. Cornell Univ. Agric. Exp. Sta. Mem. 35. P. 5 S6. 1020.

66. Stewart, I. P., The fertilization of apple orchards. Pal. State Coll. Agric. Exp. Sta. Bull. i53. I9 I\$.

67. Stewart, Robert, Sulphur in relation to soil fertility. 1ll. Agric. Exp. Sta. Bull. no. 227. I920.

68. Swassun, C. O., and Mille:, R. W., The sulphur content of some typical Kansas soils and the loss of sulphur due to cultivation. Soil science 3:130-14. I0 I 7 .

69. Tresster, D. K., The solubility of soil potash in various salt solutions. Soil Science $6: 237-257$. Jor 8 .

7o. Vendeladas, Hexry, Mamual of Mamures. igi6 (p. I 42 ).

7x. Virien, A., Abs. E. S. R. i 7:05J; from Monit. Sci. 4: ser. iq. no. 2. 773-779. 1905.

72. Vooritees, E. B., Fertilizers. igi7. Revised ed., p. II6.

73. Waringtun, R., Reprint from Jour. Chem. Soc. 47. I 885. 


LIBRARY OF CONGRESS

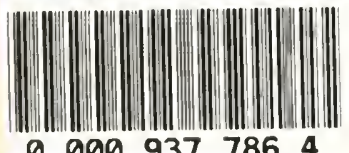

00009377864 